\title{
Biosynthesis of rat liver pyruvate kinase
}

\author{
Measurement of enzyme lifetime and the rate of synthesis at weaning
}

\author{
Timothy J. HOPKIRK and David P. BLOXHAM \\ Department of Biochemistry, School of Biochemical and Physiological Sciences, University of Southampton, \\ Southampton SO9 3TU, U.K.
}

(Received 14 March 1980/Accepted 18 June 1980)

\begin{abstract}
Sodium dodecyl sulphate/polyacrylamide-gel electrophoresis of immunoprecipitates of liver cytosol with anti-(L-type pyruvate kinase) serum revealed proteins of mol.wt. 56000 and 42000 in addition to the heavy and light chains. The ratio of the 56000 mol.wt. to the $42000 \mathrm{~mol}$.wt. protein increased under dietary conditions that resulted in an increase in the apparent specific activity of hepatic pyruvate kinase. The 42000 mol.wt. protein was removed from immunoprecipitates if the liver cytosol was partially purified by $\mathrm{pH}$ precipitation and $\left(\mathrm{NH}_{4}\right)_{2} \mathrm{SO}_{4}$ fractionation before addition of the antiserum. This technique may be used to analyse the formation of pure L-type pyruvate kinase in liver. By using $\mathrm{H}^{14} \mathrm{CO}_{3}{ }^{-}$labelling, the $t_{\frac{1}{2}}$ of L-type pyruvate kinase was estimated as $75 \pm 1.7 \mathrm{~h}$ in post-weaned high-carbohydrate-diet-fed rats. Before weaning there was little immunoreactive pyruvate kinase in rat liver cytosol. Induction began between 6 and $24 \mathrm{~h}$ after weaning and reached a maximum value $120 \mathrm{~h}$ after weaning. When clearly enhanced total pyruvate kinase activity was first observed at $24 \mathrm{~h}$ post-weaning, the apparent specific activity of hepatic pyruvate kinase was considerably lower than the specific activity of the pure isolated enzyme. When the induction of L-type pyruvate kinase was monitored by the incorporation of $\mathrm{L}-\left[4,5-{ }^{3} \mathrm{H}\right]$ leucine, the maximum rate of synthesis occurred $24-48 \mathrm{~h}$ after weaning. After this period synthesis declined, indicating a relatively slow turnover of the enzyme once the enzyme concentration was established in the liver.
\end{abstract}

Pyruvate kinase (ATP-pyruvate 2-O-phosphotransferase, EC 2.7.1.40) occupies a key position in the control of hepatic metabolism, since regulation of activity could influence the rate of gluconeogenesis (Feliu et al., 1976, 1977), the rate of glycolysis (Scrutton \& Utter, 1968; Seubert \& Schoner, 1971) and the rate of fatty acid synthesis (Ochs \& Harris, 1978). The main isoenzyme in liver, the L-type isoenzyme (for a review see Engström, 1978), is subject to a complex pattern of regulation. The enzyme shows co-operative binding of phosphoenolpyruvate (Rozengurt et al., 1969) and is subject to regulation by a number of allosteric ligands, including fructose 1,6-bisphosphate (Taylor \& Bailey, 1967; Ekman et al., 1976) and alanine (Seubert et al., 1968). All of these processes are in turn influenced by the fact that the enzyme is susceptible to phosphorylation by cyclic AMPdependent protein kinase (Ljungstrom et al., 1974;

Abbreviation used: SDS, sodium dodecyl sulphate.
Ekman et al., 1976). Phosphorylation of L-type pyruvate kinase may be regarded as inhibitory to enzyme activity (Foster \& Blair, 1978). There is now clear evidence that phosphorylation of the enzyme is stimulated by glucagon both in vivo and in vitro (Blair et al., 1976; Feliu et al., 1976; Ekman et al., 1976; Van Berkel et al., 1977; Riou et al., 1978). These observations suggest that phosphorylation is a major contributing factor in the stimulation of gluconeogenesis and the inhibition of fatty acid synthesis by glucagon.

The concentration of L-type pyruvate kinase is also closely regulated by dietary conditions (Krebs \& Eggleston, 1965), which presumably reflect hormonal concentration. Experiments with enzyme activity measurements revealed increased activity on feeding (Hopkirk \& Bloxham, 1979) or weaning (Weber et al., 1965; Taylor et al., 1967; Vernon \& Walker, 1968a,b) and decreased activity on starvation (Van Berkel et al., 1977, 1978). More recent studies by immunological techniques revealed 
that this situation could be more complex, since the apparent specific activity of enzyme was lower in liver cytosol compared with pure enzyme, owing to the presence of immunoreactive, but catalytically inactive, protein (Kohl \& Cottam, 1976, 1977; Hopkirk \& Bloxham, 1979). Furthermore, the apparent specific activity appeared to alter with dietary status. We decided to investigate this phenomenon further by analysing the biosynthesis of the enzyme at weaning by quantitative immunological techniques.

\section{Materials and methods}

The experimental procedures for the isolation of pure rat L-type pyruvate kinase, the preparation of rabbit anti-(L-type pyruvate kinase) sera, quantitative immunotitration and the assay of hepatic pyruvate kinase were exactly as described previously (Hopkirk \& Bloxham, 1979). A unit of enzyme activity is defined as the amount of enzyme producing $1 \mu \mathrm{mol}$ of pyruvate $/ \mathrm{min}$ at $37^{\circ} \mathrm{C}$. The effects of inhibitory ligands on L-type pyruvate kinase were eliminated by performing assays in the presence of the activator $0.5 \mathrm{~mm}$-fructose 1,6 bisphosphate (Ekman et al., 1976). All chemicals were routinely obtained from BDH, Poole, Dorset, U.K. or from Boehringer Corp. (London), Lewes, Sussex, U.K. Radioisotopes were purchased from The Radiochemical Centre, Amersham, Bucks., U.K.

\section{Controlled weaning}

Litters were kept with the mother until day 20 after birth on a raised wire platform which allowed all food particles to drop out of reach of the pre-weaned rats. At day 20 all food was removed from the cage to ensure that the pre-weaned rats kept to maternal milk. At $09: 00 \mathrm{~h}$ on day 21 the mother was removed from the cage and rats were provided with either high-carbohydrate, low-fat diet or moistened chow pellets ad libitum.

\section{Liver extracts}

All experiments involving enzyme fractionation were performed at $4^{\circ} \mathrm{C}$. Homogenates $(10 \%$, w/v) of liver were prepared in $250 \mathrm{~mm}$-sucrose containing $1 \mathrm{~mm}$-dithiothreitol and $1 \mathrm{~mm}$-EDTA, $\mathrm{pH} 7$. The homogenate was centrifuged at $18000 \mathrm{~g}$ for $20 \mathrm{~min}$ to produce a liver fraction for enzyme assay.

For partial purification of liver extracts, usually $1-3 \mathrm{~g}$ of liver was processed. The initial extract was prepared as described above and assayed to determine the total enzyme activity. A high speed supernatant was then prepared by centrifugation at $100000 \mathrm{~g}$ for $60 \mathrm{~min}$. The supernatant was adjusted to pH 5.0 with $1 \mathrm{M}$-acetic acid. After $5 \mathrm{~min}$, insoluble protein was removed by centrifugation at $10000 \mathrm{~g}$ for $10 \mathrm{~min}$ and the supernatant was neutralized to $\mathrm{pH} 7.0$ with $1 \mathrm{M}-\mathrm{K}_{2} \mathrm{HPO}_{4}$. A $30-50 \%$-satd. $\left(\mathrm{NH}_{4}\right)_{2} \mathrm{SO}_{4}$ fraction was prepared by conventional procedures. The pellet was dissolved in $10 \mathrm{ml}$ of $20 \mathrm{~mm}$-potassium phosphate buffer, $\mathrm{pH} 7.2$, containing $0.1 \mathrm{~mm}$-dithiothreitol and $0.1 \mathrm{~mm}$-fructose 1,6-bisphosphate, and dialysed for $18 \mathrm{~h}$ against 5 litres of the same buffer. The enzyme activity was then measured again to determine the percentage recovery. Routinely this was $80-85 \%$. Radioisotope incorporation into L-type pyruvate kinase was corrected for loss during partial purification.

\section{Immunoprecipitation of L-type pyruvate kinase}

Rats were injected intraperitoneally with either $100 \mu \mathrm{Ci}$ of $\mathrm{L}-\left[4,5-{ }^{3} \mathrm{H}\right]$ leucine or $400 \mu \mathrm{Ci}$ of $\mathrm{NaH}^{14} \mathrm{CO}_{3}$ to obtain adequate incorporation of radioactivity into the liver samples.

Antiserum ( $1 \mathrm{ml}$ ) was added to 60 units of enzyme in the liver extract. After $1-2 \mathrm{~h}$ the inhibition of enzyme activity was confirmed by assay. If greater than $90 \%$ inhibition was obtained the sample was layered over $1 \mathrm{ml}$ of $0.5 \mathrm{M}$-sucrose in phosphatebuffered saline, pH $7.2(0.8 \% \mathrm{NaCl}, 0.02 \% \mathrm{KCl}$, $0.115 \% \mathrm{Na}_{2} \mathrm{HPO}_{4}$ and $0.02 \% \mathrm{KH}_{2} \mathrm{PO}_{4}$ ) containing $0.1 \%$ Triton $\mathrm{X}-100$ and the immunoprecipitate was obtained by centrifugation at $10000 \mathrm{~g}$ for $20 \mathrm{~min}$. The pellet was suspended in $3 \mathrm{ml}$ of phosphatebuffered saline containing $0.1 \%$ Triton X-100 and spun through the sucrose cushion again. This step was repeated once more. When radioactive incorporation was measured, the protein was dissolved in $1 \mathrm{ml} 90 \%(\mathrm{w} / \mathrm{v})$ formic acid and an aliquot was counted in $0.8 \%$ butyl-PBD [5-(4biphenylyl)-2-(4-t-butylphenyl-1-oxa-3,4-diazole)] in toluene by using an Intertechnique ABAC SL 30 liquid-scintillation counter. When the protein content of immunoprecipitates was determined the pellet was dissolved in $500 \mu \mathrm{l}$ of $0.1 \mathrm{M}-\mathrm{NaOH}$ and protein was determined with Folin-Ciocalteau reagent (Lowry et al., 1951).

When immunoprecipitates were analysed by SDS/polyacrylamide gel electrophoresis, the protein was solubilized in $10 \mathrm{~mm}$-sodium phosphate, $\mathrm{pH} 7.0$, containing $1 \%(\mathrm{w} / \mathrm{v})$ SDS and $1 \mathrm{~mm}-2$ mercaptoethanol. SDS/polyacrylamide gel electrophoresis was performed by using the procedure of Weber \& Osborn (1969) with $10 \%$ (w/v) polyacrylamide slab gels (Figs. 1 and 2 ) or $7.5 \%$ (w/v) polyacrylamide cylindrical gels (Fig. 8). Slab gels stained by Coomassie Brilliant Blue were vacuum dried and photographed (Figs. 1 and 2). Cylindrical gels were sliced into $2 \mathrm{~mm}$ bands and the gel was solubilized in NCS tissue solubilizer (Searle-Amersham) for liquid-scintillation counting.

The incorporation of $\mathrm{L}-\left[4,5-{ }^{3} \mathrm{H}\right]$ leucine into total cell protein was assayed by the filter paper disc method (Dunaway \& Weber, 1974). 


\section{Results}

Protein species precipitated by anti-(liver pyruvate kinase) serum

To analyse proteins precipitated by anti-(liver pyruvate kinase) serum L-type pyruvate kinase in liver cytosol from chow diet-fed (Fig. 1) rats was precipitated with excess anti-(liver pyruvate kinase) serum and the pellets were obtained by centrifugation. Fig. 1 shows that, as well as a 56000 mol.wt. protein, additional protein bands at mol.wts. 100000 and 42000 were clearly identified All these bands were absent when cytosol was mixed with pre-immune serum (Fig. 1; tracks 5 and 7). The pattern of immunoprecipitated proteins was not altered by the inclusion of Triton $\mathrm{X}-100$ during isolation (Fig. 1) so the detergent was routinely included. The appearance of the $42000 \mathrm{~mol}$.wt. protein on the gels was not affected by the inclusion of $1 \mathrm{~mm}$-phenylmethanesulphonyl fluoride, an inhibitor of proteolytic enzymes (Fahrney \& Gold, 1963), in all the preparation buffers. The highmolecular-weight-protein fraction was present in variable concentration and it was virtually indistinguishable by electrophoresis from liver pyruvate kinase dimer. Its presence on the gels may result from incomplete reduction of disulphides in immunoprecipitates, since these were fairly resistant to solubilization. The concentration of the 42000 mol.wt. protein was dependent on the source of the liver. The concentration of the protein was higher in the liver of chow-fed rats (ratio of mol.wt.
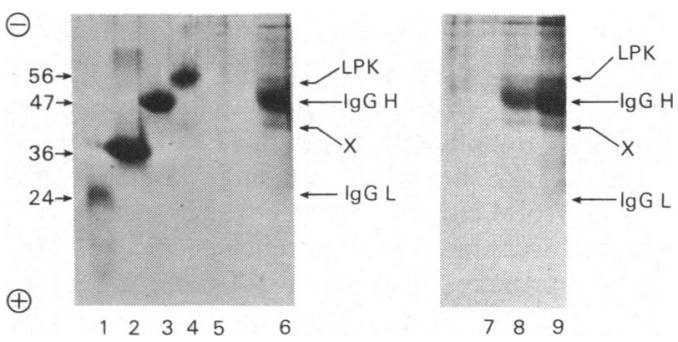

Fig. 1. Immunoprecipitation of pyruvate kinase from liver cytosol of chow-fed rats

The tracks on the slab gel were as follows: $1,5 \mu \mathrm{g}$ of chymotrypsin; $2,20 \mu \mathrm{g}$ of lactate dehydrogenase; 3 , $20 \mu \mathrm{g}$ of citrate synthase; $4,10 \mu \mathrm{g}$ of L-type pyruvate kinase; 5 , 'blank immunoprecipitate' of liver cytosol with pre-immune serum; $6,20 \mu \mathrm{g}$ of immunoprecipitate of liver cytosol; 7, 'blank immunoprecipitate' of liver cytosol; $8,10 \mu \mathrm{g}$ of immunoprecipitate; $9,20 \mu \mathrm{g}$ of immunoprecipitate. Samples 5 and 6 were processed in the presence of $0.1 \%$ Triton $\mathrm{X}-100$. The mol. wt. of $\mathrm{X}$ was calculated to be 42000 . Abbreviations: LPK, L-type pyruvate kinase, IgGH and IgGL, immunoglobulin $\mathrm{G}$ heavy and light chains.
42000 : mol.wt. $56000,2: 1)$ compared with the liver of high-carbohydrate-diet-fed rats (mol.wt. 42000:mol.wt. 56000, 0.7:1; results not shown). This is consistent with the observed higher specific activity for pyruvate kinase in the liver of highcarbohydrate-diet-fed rats compared with chow-fed rats (Kohl \& Cottam, 1977; Hopkirk \& Bloxham, 1979). The $42000 \mathrm{~mol}$.wt. protein was absent from immunoprecipitates of pure liver pyruvate kinase (Hopkirk \& Bloxham, 1979).

In a previous paper (Hopkirk \& Bloxham, 1979) we reported that, if liver cytosol was partially purified by precipitation at $\mathrm{pH} 5.0$ and $\left(\mathrm{NH}_{4}\right)_{2} \mathrm{SO}_{4}$ fractionation, the specific activity of this fraction measured by immunological techniques was identical with that of pure liver pyruvate kinase. This observation means that any antigenic, but catalytically inactive, proteins such as the 42000 mol.wt. protein would not be precipitated if antiserum was added to partially-purified liver cytosol. This was confirmed experimentally (Fig. 2). Essentially all traces of 42000 mol.wt. protein were absent from immunoprecipitates when partially purified liver cytosol fractions were from either high-carbohydrate-diet or chow-fed rats.

\section{Estimation of the half-life of hepatic pyruvate kinase in vivo}

To describe the system for pyruvate kinase biosynthesis more fully we felt that it was important to establish the lifetime of the L-type pyruvate kinase subunit (mol.wt. 56000) in vivo under stable metabolic conditions.

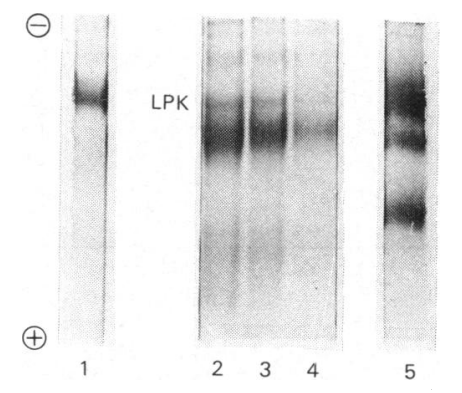

Fig. 2. Immunoprecipitation of pyruvate kinase from partially purified liver cytosol

Liver cytosol fractions of high-carbohydrate-diet fed rats were partially purified as described in the Materials and methods section. The tracks on the slab gel were as follows: $1,10 \mu \mathrm{g}$ of L-type pyruvate kinase; $2,20 \mu \mathrm{g}$ of immunoprecipitate; $3,10 \mu \mathrm{g}$ of immunoprecipitate; $4,5 \mu \mathrm{g}$ of immunoprecipitate; 5 , standards of mol.wt. 56000, 47000 and 36000. The results were identical if partially purified liver cytosol fractions from chow-fed rats were used. Abbreviation: LPK, L-type pyruvate kinase. 
For this experiment rats were weaned onto high-carbohydrate diet and were maintained on this diet for 2-3 weeks. At the end of this time rats were injected with $\mathrm{NaH}{ }^{14} \mathrm{CO}_{3}$ and were killed at various times afterwards. Liver tissue was freeze clamped and stored under liquid $\mathbf{N}_{2}$. Immunoprecipitates were prepared from partially purified liver cytosols and the incorporation of ${ }^{14} \mathrm{C}$ into the immunoprecipitates was determined. The loss of ${ }^{14} \mathrm{C}$ from immunoprecipitates with time followed first-order kinetics (Fig. 3). The apparent rate constant $\left(k_{\mathrm{d}}\right)$ for degradation, calculated from the slope of the straight line, was $9.2 \pm 0.2 \times 10^{-3} \mathrm{~h}^{-1}$. This gives an estimate of the half-life of L-type pyruvate kinase as $75 \pm 1.7 \mathrm{~h}$.

\section{Induction of L-type pyruvate kinase during weaning}

To study the biosynthesis of L-type pyruvate kinase and antigenically related proteins we needed to study a period of controlled induction of the enzyme. For this purpose the change in enzyme activity and concentration at weaning were

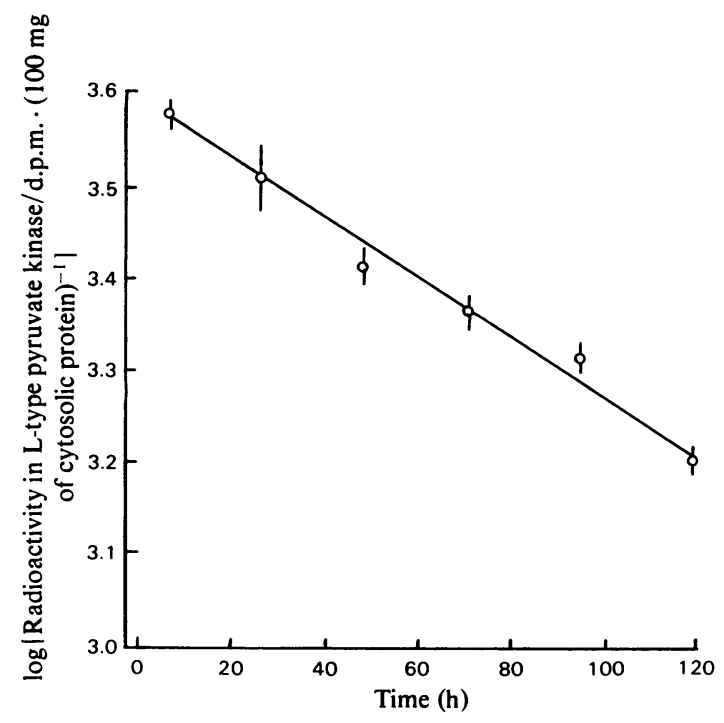

Fig. 3. Lifetime of L-type pyruvate kinase in liver of rats fed on a high-carbohydrate diet

At time zero rats were injected wtih $400 \mu \mathrm{Ci}$ of $\mathrm{NaH}^{14} \mathrm{CO}_{3}$. At various time intervals rats were killed, liver cytosol fractions were prepared and partially purified. Before addition of antiserum all enzyme fractions were adjusted to a constant concentration of activity to eliminate any variation due to differential enzyme recovery and sufficient antiserum to precipitate the enzyme was added. The half-life was calculated from the first order rate equation $t_{1}=0.693 / k_{\mathrm{d}}$ where $k_{\mathrm{d}}$ is the apparent rate constant for loss of ${ }^{14} \mathrm{C}$ from L-type pyruvate kinase. Results are shown as means \pm S.E.M.. monitored. At this time there is a dramatic increase in heaptic pyruvate kinase activity, which is closely linked to increased fatty acid synthesis (Smith \& Abraham, 1970).

Wistar Albino rats were weaned at $09: 00 \mathrm{~h}$ on day 21 after birth and this is designated as zero-time in subsequent experiments. Litters were fed either the chow diet (Fig. 4) or the high-carbohydrate diet (Fig. 5) ad libitum. At appropriate times, the total enzyme activity, the immunotitratable protein and the apparent enzyme specific activity were measured. The total activity of the enzyme in liver extracts was low before weaning and increased significantly between 6 and $24 \mathrm{~h}$ after weaning. Those animals weaned onto the high-carbohydrate diet showed an activity 5-fold that of chow-fed animals. Also, the induction of enzyme activity was more rapid on the high-carbohydrate diet (Fig. 5). The induction of enzyme protein, as judged by immunotitration, began approximately $24 \mathrm{~h}$ after weaning (Figs. 4 and 5). The amount of enzyme protein was also greater in high-carbohydrate-diet fed rats. After $72 \mathrm{~h}$, the amount of immunoreactive protein and the total enzyme activity in the liver extracts of both groups became approximately constant.

Division of the enzyme activity by the concentration of immunoreactive protein enables estimation of the apparent enzyme specific activity. For pure L-type pyruvate kinase the enzyme specific activity was estimated at 200 units/mg of enzyme protein under the conditions employed for the immunotitration experiments. Before weaning the apparent enzyme specific activity was very low (Figs. 4 and 5). On weaning, the highest specific activity $(80-100$ units $/ \mathrm{mg})$ was obtained for the high-carbohydrate-diet fed animals. The apparent specific activity of the enzyme actually declined by a small, but significant, amount $(P<0.05)$ between $72 \mathrm{~h}$ and $120 \mathrm{~h}$ after weaning. When clearly enhanced total enzyme activity was first observed at $24 \mathrm{~h}$ post weaning, the apparent specific activity of hepatic pyruvate kinase $(80-100$ units $/ \mathrm{mg}$ of protcin) was still lower than the specific activity of the pure isolated enzyme. This result could be achieved only if L-type pyruvate kinase and the additional antigenic proteins share virtually identical patterns of induction at weaning.

\section{Quantitative immunotitration of L-type pyruvate kinase in the presence of cytosol}

We have provided evidence that the low apparent specific activity of pyruvate kinase in liver cytosol was due to the presence of antigenic proteins closely related to pyruvate kinase. An alternative explanation was that, in the presence of liver cytosol, the titration of liver pyruvate kinase was influenced in some unexpected way. The latter possibility was 


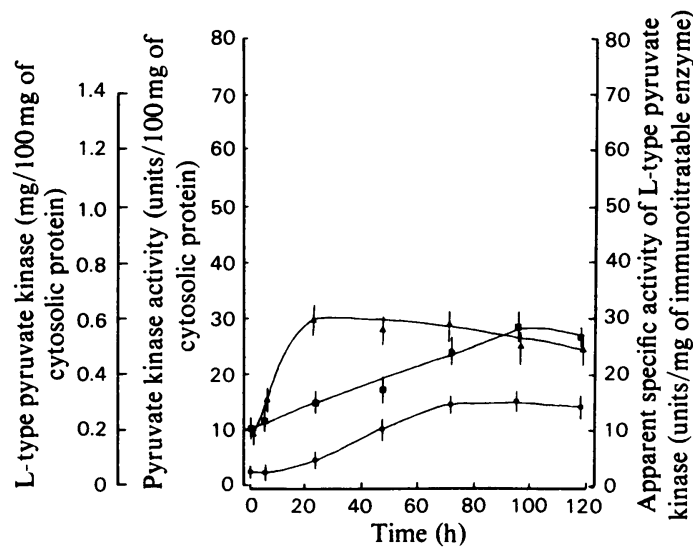

Fig. 4. Changes in L-type pyruvate kinase during weaning on a chow diet

Rats were weaned onto chow diet at 09:00h on day 21 after birth (time zero). Total hepatic pyruvate kinase activity (O), total antigenic pyruvate-kinaselike protein $(\square)$ and the apparent specific activity of the immunotitratable protein $(\boldsymbol{A})$ were determined as described in the Materials and methods section. The axes on the graph are on the same scale as that presented in Fig. 5 to allow direct comparison. Results are shown as the mean values of at least 12 observations \pm S.E.M.

eliminated by control experiments involving the addition of pure L-type pyruvate kinase to the cytosols from pre-weaned and weaned rat livers.

Liver extracts were first prepared from preweaned rats on day 18 after birth. Assay for total hepatic pyruvate kinase showed $0.4 \pm 0.08$ (S.E.M.; $n=12$ ) units of enzyme activity/ml. Pure L-type pyruvate kinase was added to the extracts to raise the activity to 4 units $/ \mathrm{ml}$ of extract. These 'doped' extracts were titrated against anti-(L-type pyruvate kinase) serum and the neutralization of enzyme activity was contrasted with a titration against an identical amount of pure L-type pyruvate kinase (Fig. 6). Clearly the equivalence point of both titrations was virtually identical, showing that the presence of liver cytosolic proteins does not interfere with titration. This result is consistent with the previous demonstration that there is virtually no antigenic form of L-type pyruvate kinase in the liver of the pre-weaned rat.

To show that the point of equivalence was proportional to the enzyme concentration in the liver extract, rats weaned onto a high-carbohydrate diet were used. These animals had a total hepatic pyruvate kinase activity at $37^{\circ} \mathrm{C}$ of $7.0 \pm 0.4$ (mean \pm S.E.M.; $n=12$ ) units $/ \mathrm{ml}$ of extract. Pure enzyme was added to samples of these extracts to double the original activity. In the presence of a constant amount of antiserum, the equivalence point

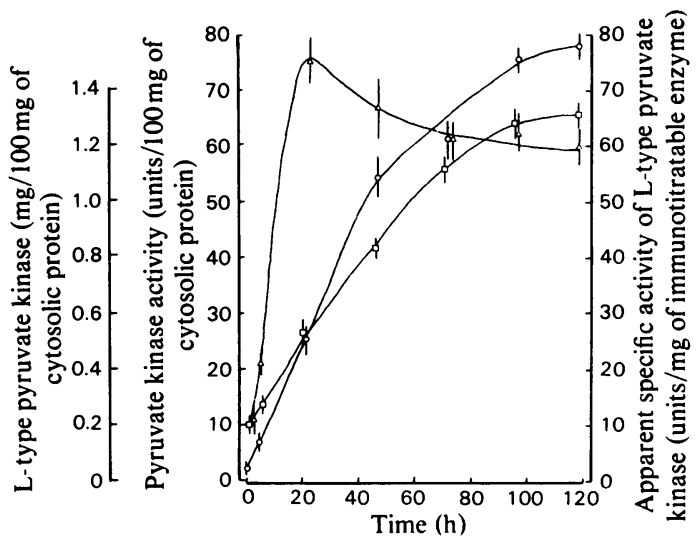

Fig. 5. Changes in L-type pyruvate kinase during weaning on a high-carbohydrate diet

Total hepatic pyruvate kinase activity $(O)$, total antigenic pyruvate kinase-like protein $(\square)$ and the apparent specific activity of the immunotitratable protein $(\Delta)$ were determined as 21 -day-old rats were weaned onto a high-carbohydrate diet. Other details are as for Fig. 4.

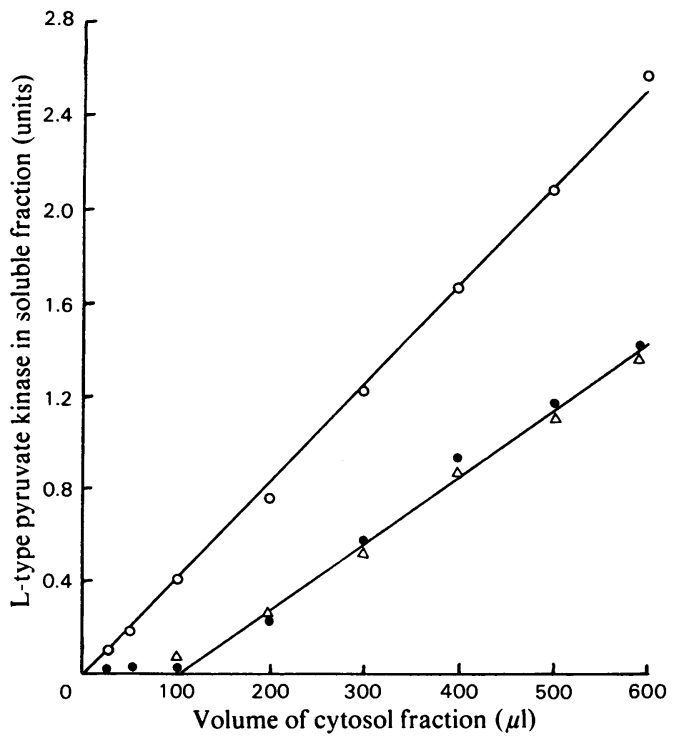

Fig. 6. Immunotitration of L-type pyruvate kinase added to liver cytosol fractions from pre-weaned rats

Liver cytosol fractions were prepared from 18-day old rats. Pure L-type pyruvate kinase was added to increase the enzyme activity to $4 \mathrm{units} / \mathrm{ml}$ and the following titrations were performed; $O$, pre-immune serum versus pure L-type pyruvate kinase ( 4 units/ $\mathrm{ml}) ; 0$, antiserum versus pure L-type kinase (4 units $/ \mathrm{ml}) ; \Delta$, antiserum versus pure L-type pyruvate kinase added to liver cytosol from preweaned rats. 
was approximately halved by this procedure (Fig. 7). Thus any change in the position of equivalence was inversely proportional to the change in the concentration of enzyme protein present in the extract.

The presence of pre-immune serum had no effect on the activity of hepatic pyruvate kinase during incubation. Therefore the presence of pre-immune rabbit serum serves as a control for any non-specific precipitation.

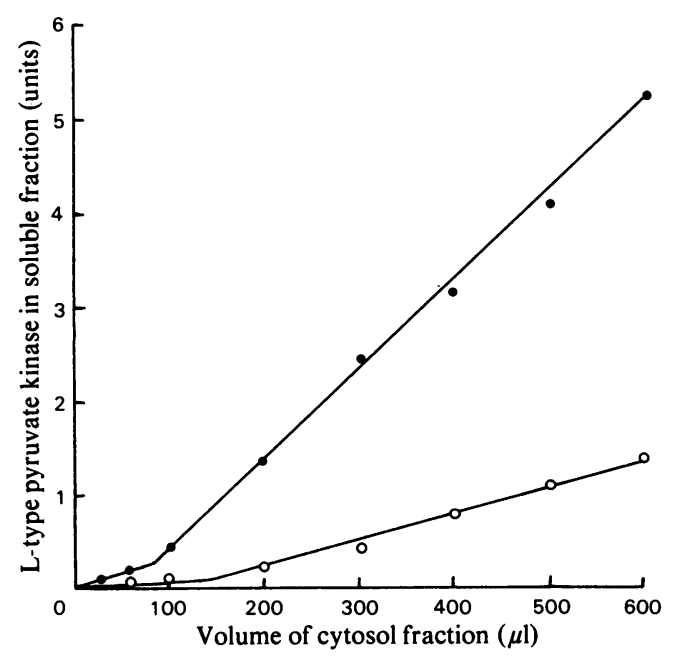

Fig. 7. Effect on the equivalence point in immunotitration of adding pure L-type pyruvate kinase to cytosol fractions Liver cytosol fraction was isolated from highcarbohydrate-diet fed rats and the activity of L-type pyruvate kinase was measured. Sufficient pure enzyme was then added to a sample to exactly double the enzyme activity. Immunotitrations with a fixed amount of antiserum were then performed with either the original extract $(0)$ or the extract with added L-type pyruvate kinase ( $(\bullet)$.

\section{Protein content of immunoprecipitates during weaning}

The previous experiments have relied almost exclusively upon enzyme neutralization to estimate L-type pyruvate kinase concentration in liver extracts. The amount of enzyme can also be estimated from the concentration of protein in the immunoprecipitate. We decided to adopt this approach to check the earlier measurements (i.e. Figs. 4 and 5) and to demonstrate quantitatively the presence of additional antigenic proteins. Liver extracts from pre-weaned and $72 \mathrm{~h}$ high-carbohydrate-diet weaned rats were prepared and the total enzyme content was assayed. Immunoprecipitates were then prepared under conditions of antibody limitation and antibody excess (Table 1). The limitation condition was judged by adding enough anti-(L-type pyruvate kinase) serum just to neutralize 12 units of pure enzyme in a standard incubation. The excess condition was judged by adding enough anti-(L-type pyruvate kinase) serum to neutralize all enzyme activity in a sample from a weaned liver. This amount of antiserum neutralized 30 units of pure enzyme. Control incubations were performed in the presence of pre-immune serum.

In the presence of limited antiserum all the activity was neutralized in both the pure enzyme and the liver extract from pre-weaned rats but only $58 \%$ was inhibited in the liver extract of weaned rats (Table 1). As not all the activity was inhibited in the liver extracts of weaned rats, this implies that there was additional antigenic protein in the cytosol fraction competing for the antibody-binding domains. Consistent with this deduction is the observation that, in the liver extract of weaned rats, the amount of protein precipitated was virtually identical with that in the incubation with pure enzyme. In contrast, the amount of immunoprecipitated protein was considerably lower when the liver extract of preweaned rats was used.

Table 1. Protein content of immunoprecipitates prepared from liver extracts of pre-weaned and weaned rats under conditions of antibody limitation and excess

Immunoprecipitations were performed on $2 \mathrm{ml}$ of liver cytosol fraction (see the Materials and methods section) derived from $200 \mathrm{mg}$ of liver. In antibody 'limitation' sufficient antiserum to neutralize 12 units of pure L-type pyruvate kinase was added, whereas in the 'excess' condition sufficient antiserum to neutralize 30 units of L-type pyruvate kinase was added. Results are presented as means \pm S.E.M. $(n=12)$.

\begin{tabular}{|c|c|c|c|c|}
\hline \multirow[b]{2}{*}{ Antibody } & \multirow{2}{*}{$\begin{array}{l}\text { Source of L-type } \\
\text { pyruvate kinase }\end{array}$} & \multicolumn{2}{|c|}{ Enzyme (units) } & \multirow{2}{*}{$\begin{array}{c}\text { Protein } \\
\text { precipitated }(\mu \mathrm{g})\end{array}$} \\
\hline & & Before antibody & After antibody & \\
\hline Limitation & $\begin{array}{l}\text { Pure enzyme } \\
\text { Pre-weaned rats } \\
\text { Weaned rats }\end{array}$ & $\begin{array}{c}12 \\
0.9 \pm 0.24 \\
12 \pm 1.5\end{array}$ & $\begin{array}{c}0 \\
0 \\
5 \pm 1.25\end{array}$ & $\begin{array}{l}500 \pm 30 \\
140 \pm 15 \\
560 \pm 20\end{array}$ \\
\hline Excess & $\begin{array}{l}\text { Pure enzyme } \\
\text { Pre-weaned rats } \\
\text { Weaned rats }\end{array}$ & $\begin{array}{c}12 \\
0.9 \pm 0.24 \\
12 \pm 1.5\end{array}$ & $\begin{array}{l}0 \\
0 \\
0\end{array}$ & $\begin{array}{l}470 \pm 20 \\
160 \pm 15 \\
870 \pm 30\end{array}$ \\
\hline
\end{tabular}


In the presence of excess antibody the enzyme present in all three incubations was completely neutralized. The immunoprecipitated protein was not increased in either the incubations with pure enzyme or liver extracts from pre-weaned rats, but there was a significant $(P<0.05)$ increase in the immunoprecipitated protein when liver extracts from weaned rats were used. The increase in total immunoprecipitated protein from the pre-weaned to weaned state (5-fold) was virtually identical with the titrated increase in L-type pyruvate kinase at $72 \mathrm{~h}$ (Fig. 5).

Knowing that the total immunoprecipitated protein for $60 \mu \mathrm{g}$ of pure L-type pyruvate kinase (equivalent to 12 units) was $485 \pm 15 \mu \mathrm{g}$ (Table 1) we can calculate that $870 \pm 35 \mu \mathrm{g}$ of immunoprecipitated protein from the liver extract of weaned rats contains $108 \mu \mathrm{g}$ of immunoreactive pyruvatekinase-like protein. This corresponds to $540 \mu \mathrm{g}$ of pyruvate-kinase-like protein/g wet wt. of liver and may be contrasted with the titration value (Fig. 5) which showed an increase of $800 \pm 50 \mu \mathrm{g}$ of pyruvate-kinase-like protein/g wet wt. of liver over $72 \mathrm{~h}$ of weaning. The observation that the measured protein precipitate was only $67 \%$ of the value predicted by immunotitration is consistent with the competing antigenic proteins having a mol.wt. less than 56000 .

\section{Incorporation of $\mathrm{L}-\left[4,5-{ }^{3} \mathrm{H}\right]$ leucine into L-type pyruvate kinase in vivo}

To obtain information on the rate of biosynthesis of pyruvate kinase during weaning the synthesis of enzyme was monitored by following the incorporation of $100 \mu \mathrm{Ci}$ of $\mathrm{L}-\left[4,5-{ }^{3} \mathrm{H}\right]$ leucine injected in vivo. Incorporation over a $24 \mathrm{~h}$ period was measured into $(a)$ the total hepatic water-soluble radioactivity, $(b)$ total hepatic soluble protein, $(c)$ total immunoreactive pyruvate-kinase-like protein and $(d)$ immunoprecipitated L-type pyruvate kinase after partial purification of liver cytosol (Table 2). The incorporation into 'antigenically related proteins' was estimated by the subtraction of $(d)$ from $(c)$. This incorporation is primarily into the 42000 mol.wt. protein as demonstrated by SDS/ polyacrylamide-gel electrophoresis.

Because the rats increased in weight during the course of the experiment, the labelling of the amino-acid pool and the total hepatic protein decreased progressively. This decrease is sufficiently small for $72 \mathrm{~h}$ after weaning that any correction has a negligible effect on the final result. Therefore uncorrected data are presented in Table 2 for incorporation into pyruvate kinase. Before weaning the synthesis of L-type pyruvate kinase, or antigenically related proteins, was very low. At weaning there was, as expected, a marked increase in incorporation into pyruvate kinase. The maximum rate of synthesis occurred between 24 and $48 \mathrm{~h}$ after weaning. At this point incorporation into total hepatic pyruvate kinase represented $0.77 \%$ of the total incorporation into liver protein. The increase in incorporation $48 \mathrm{~h}$ after weaning represented a 6-8.5-fold stimulation of synthetic rate when compared with the pre-weaned rats. After $48 \mathrm{~h}$, the synthesis of L-type pyruvate kinase declined significantly so that when the enzyme content of the tissue was virtually at its peak value (i.e. 61 units/g wet wt.) then incorporation was at its lowest value in the weaned rat. This implies that turnover of L-type pyruvate kinase is relatively slow and is quite consistent with the estimation for $t_{\frac{1}{2}}$ of the enzyme at $75 \mathrm{~h}$ (Fig. 3). There was a significant increase in incorporation into the antigenically related protein fraction, which occurred within the first $24 \mathrm{~h}$ after weaning and therefore this fraction is formed on the

Table 2. Labelling of L-type pyruvate kinase and antigenically related proteins during weaning Rats were injected with $100 \mu \mathrm{Ci}$ of $\mathrm{L}-\left[4,5-{ }^{3} \mathrm{H}\right]$ leucine at the appropriate stage of development and the incorporation into various liver fractions was measured over a $24 \mathrm{~h}$ period. Immunoprecipitation was performed on either liver cytosol fractions to obtain total hepatic pyruvate kinase or on partially purified extracts. The incorporation into immunoprecipitates was corrected for a small non-specific precipitation which occurred in the presence of preimmune serum. Results are presented as means \pm S.E.M. $(n=12)$.

$\begin{array}{cc}\begin{array}{c}\text { Time of } \\ \text { experiment }\end{array} & \begin{array}{c}\text { radioactivity } \\ \text { (d.p.m./g wet wt.) }\end{array} \\ \text { Pre-weaning } & 3.5 \pm 0.2 \\ \text { (15 days old) } & \\ \text { After weaning } & \\ 0-24 \mathrm{~h} & 2.98 \pm 0.1 \\ 24-47 \mathrm{~h} & 2.6 \pm 0.15 \\ 48-72 \mathrm{~h} & 2.4 \pm 0.08\end{array}$

Vol. 192
Amount of L-type

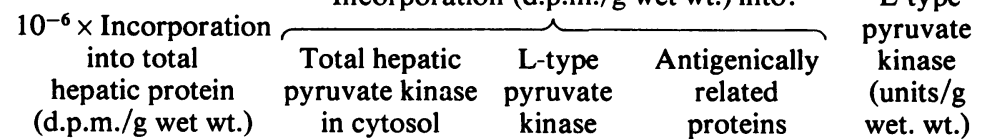
$\begin{array}{lllll}1.7 \pm 0.1 & 1000 \pm 150 & 800 \pm 100 \quad- & 3.7\end{array}$

$\begin{array}{lllll}1.4 \pm 0.12 & 5715 \pm 600 & 3730 \pm 400 & 1985 & 29.8 \\ 1.1 \pm 0.05 & 8450 \pm 800 & 4830 \pm 400 & 3620 & 53 \\ 1.1 \pm 0.06 & 5330 \pm 450 & 2070 \pm 220 & 3260 & 61\end{array}$


same time scale as is L-type pyruvate kinase. The rapid formation within $24 \mathrm{~h}$ is consistent with the decreased apparent specific activity of pyruvate kinase at the start of weaning (Figs. 4 and 5). Peak synthesis of the antigenically related proteins occurs between 24 and $48 \mathrm{~h}$ but there is only a small decrease between 48 and $72 \mathrm{~h}$ in contrast with the decrease in L-type pyruvate kinase synthesis. This means that the ratio of synthesis of L-type pyruvate kinase to synthesis of antigenically related protein decreased from 1.88 at $24 \mathrm{~h}$ to 0.63 at $72 \mathrm{~h}$. This is consistent with the fall in apparent pyruvate kinase activity observed during weaning (Figs. 4 and 5).

The distribution of radioactivity into various proteins in the immunoprecipitates was determined by SDS/polyacrylamide-gel electrophoresis on cylindrical gels. When the total immunoprecipitated hepatic pyruvate kinase in cytosol was analysed then major radioactive protein bands were identified at mol.wts. 56000 (L-type pyruvate kinase) and 42000 (Fig. 8). The only other candidate for a labelled protein in the immunoprecipitate was at mol.wt. 23000. This contained less radioactivity

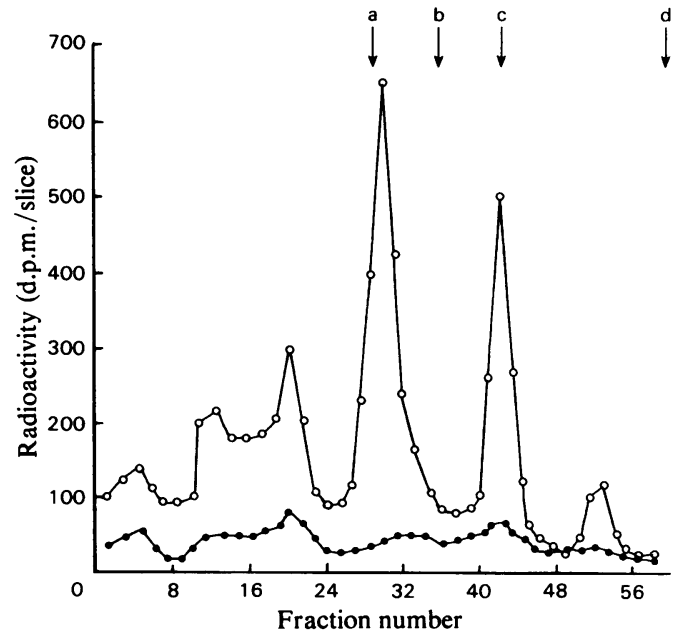

Fig. 8. Radioactive labelling of total immunoreactive forms of pyruvate-kinase-like proteins

The incorporation of $\mathrm{L}-\left[4,5-{ }^{3} \mathrm{H}\right]$ leucine $(100 \mu \mathrm{Ci})$ was measured $24-48 \mathrm{~h}$ after weaning onto highcarbohydrate diet. Immunoprecipitation was performed on liver cytosol extracts without any purification. Analysis of the immunoprecipitates -with antiserum (O) or pre-immune serum (O) was performed by SDS/polyacrylamide-gel $(7.5 \%$ crosslinked) electrophoresis on cylindrical gels. The arrows mark the positions of molecular weight markers; a, L-type pyruvate kinase; $b$, heavy chain of immunoglobulin; c, 42000 mol.wt. protein: d, light chain of immunoglobulin. The position of the markers was located from the relative mobility on parallel gels which were stained for protein. than the $42000 \mathrm{~mol}$.wt. protein, indicating that it is the latter protein that is the main candidate as the antigenically related protein immunoprecipitated by anti-(L-type pyruvate kinase) serum. When the immunoprecipitate from partially purified liver cytosols was analysed, predominantly L-type pyruvate kinase was identified by radioactivity incorporation on the gel (results not shown). This confirms the validity of the method used for measuring L-type pyruvate kinase synthesis (Table 2).

\section{Discussion}

Immunoprecipitation of L-type pyruvate kinase from liver cytosol

The presence of a competing antigenic protein of mol.wt. 42000 interferes with the analysis of the biosynthesis of the L-type pyruvate kinase subunit, mol.wt. 56000. The present work shows that its effects can be eliminated from consideration by partial purification of the liver cytosol before any immunotitration or immunoprecipitation experiments.

The lifetime of pyruvate kinase was estimated by monitoring labelling of the immunoprecipitated protein of mol.wt. 56000 with $\mathrm{NaH}^{14} \mathrm{CO}_{3}$. The use of $\mathrm{NaH}^{14} \mathrm{CO}_{3}$ to follow the degradation of liver proteins was suggested by Swick \& Ip (1974). The method has been used to estimate the turnover of several individual proteins by immunological methods similar to that employed here, e.g. liver phosphofructokinase $\left(t_{\frac{1}{2}} 43 \mathrm{~h}\right.$; Dunaway et al., 1978) and liver fructose 1,6-bisphosphatase $\left(t_{\frac{1}{2}} 45 \mathrm{~h}\right.$; Zalitis \& Pitot, 1979). The half-life of L-type pyruvate kinase was estimated as $75 \mathrm{~h}$. This value of $75 \mathrm{~h}$ for the lifetime of the enzyme is slightly longer than our previous estimate of $56 \mathrm{~h}$ for the rate of degradation of the enzyme when adult rats were starved (Hopkirk \& Bloxham, 1979. This may indicate that the rate of turnover of L-type pyruvate kinase may be influenced by the metabolic state. An attractive possibility is that the phosphorylation of L-type pyruvate kinase may enhance the susceptibility to proteolytic degradation (Bergstrom et al., 1975, 1978; Hall et al., 1979). Feeding animals a highcarbohydrate, low-fat diet would result in an enhanced plasma insulin concentration (SugawaKatayama \& Morita, 1977; Laube et al., 1978). As feeding results in an increase in the insulin: glucagon ratio (Unger, 1971; Parilla et al., 1974; Ip et al., 1977), the net effect of these changes may presumably be a decrease in the phosphorylation state of L-type pyruvate kinase (Taunton et al., 1974; Blair et al., 1976; Engstrom, 1978: Claus et al., 1979).

The estimate of $t_{\frac{1}{2}}$ as $75 \mathrm{~h}$ confirmed our previous observation (Hopkirk \& Bloxham, 1979) that the turnover of L-type pyruvate kinase was relatively 
slow compared with the induction of synthesis of the enzyme. In the present work we have shown that, at weaning onto high-carbohydrate diet, most of the synthesis of enzyme was completed within $48 \mathrm{~h}$ as judged by radioisotope incorporation, which is less than one half-life for enzyme degradation.

Before weaning there was little immunoreactive pyruvate kinase protein or incorporation of $\mathbf{L}^{-}$ $\left[4,5{ }^{3} \mathrm{H}\right]$ leucine. A clear induction of enzyme activity was observed within $6-24 \mathrm{~h}$ on weaning as judged by both of these parameters (Figs. 4 and 5 and Table 2). These results show that there is not a nascent precursor of pyruvate kinase that is only activated at weaning. The results are consistent with hormoneinduced synthesis de novo of L-type pyruvate kinase mRNA which is subsequently translated to form active protein. The peak rate of translation of L-type pyruvate kinase mRNA as judged by $\mathrm{L}-[4,5$ ${ }^{3} \mathrm{H}$ leucine incorporation must occur within $24-48 \mathrm{~h}$ after weaning. Presumably this may also be the time when mRNA concentration is maximum. The current work is the first unequivocal demonstration of the enhanced synthesis de novo of L-type pyruvate kinase at weaning and complements the original studies on the appearance of enzyme activity.

\section{Immunoreactive forms of L-type pyruvate kinase in the liver}

In addition to the L-type pyruvate kinase subunit of mol.wt. 56000 we have demonstrated the immunoprecipitation of an additional related protein of mol.wt. 42000 . If the 42000 mol.wt. protein was a proteolytic product of L-type pyruvate kinase, then we felt that its formation should lag behind pyruvate kinase, especially when one considers the relative stability of L-type pyruvate kinase as judged by its $t_{\frac{1}{1}}$. This does not seem to be the case, since firstly incorporation of $\mathrm{L}-\left[4,5-{ }^{3} \mathrm{H}\right]$ leucine into the $42000 \mathrm{~mol}$.wt. protein was observed very early in the weaning process and secondly the apparent specific activity of pyruvate kinase was low as soon as the appearance of the enzyme was detected on weaning. Currently we must presume that this protein is a gene product separate from L-type pyruvate kinase with which it shares common antigenic determinants.

Kohl \& Cottam (1977) and Hall et al., (1979) have also tried to identify related forms of L-type pyruvate kinase. They purified the enzyme from $84 \mathrm{~h}$-starved rats (normally low apparent specific activity) and identified proteins of mol.wts. 56000 and 51000 in their final preparation. The latter protein was not immunoreactive. We have already shown that attempts to co-purify antigenic proteins competing with L-type pyruvate kinase should be unsuccessful since those proteins are removed in the early step of the conventional purification procedure.

\section{Note Added in Proof (Received 15 August 1980)}

During the preparation of this paper Cladaras \& Cottam (1980) presented data showing the half-life of liver pyruvate kinase to be between 50 and $60 \mathrm{~h}$.

T. J. H. is grateful to the Science Research Council for the award of a research studentship. This work was also supported in part by the Medical Research Council.

\section{References}

Bergstrom, G., Ekman, P., Humble, E. \& Engstrom, L. (1975) FEBS Lett. 56, 288-291

Bergstrom, G., Ekman, P., Humble, E. \& Engstrom, L. (1978) Biochim. Biophys. Acta 532, 259-267.

Blair, J. B., Cimbala, M. A., Foster, J. L. \& Morgan, R. A. (1976) J. Biol. Chem. 251, 3756-3762

Cladaras, C. \& Cottam, G. L. (1980) Arch. Biochem. Biophys. 200, 426-433

Claus, T. M., El-Maghrabi, M. R. \& Pilkis, S. J. (1979) J. Biol. Chem. 254, 7855-7864

Dunaway, G. A. \& Weber, G. (1974) Arch. Biochem. Biophys. 162, 629-637

Dunaway, G. A., Leung, G. L.-Y., Thrasher, J. R. \& Cooper, M. D. (1978) J. Biol. Chem. 253, 7460-7463

Ekman, P., Dahlqvist, U., Humble, E. \& Engstrom, L. (1976) Biochim. Biophys. Acta 429, 374-382

Engstrom, L. (1978) Curr. Top. Cell. Regul. 13, 29-51

Fahrney, K. J. \& Gold, A. M. (1963) J. Am. Chem. Soc. 85, 997-1000

Feliu, J. E., Hue, L. \& Hers, H. G. (1976) Proc. Natl. Acad. Sci. U.S.A. 73, 2762-2766

Feliu, J. E., Hue, L. \& Hers, H. G. (1977) Eur. J. Biochem. 81, 609-617

Foster, J. L. \& Blair, J. B. (1978) Arch. Biochem. Biophys. 189, 263-276

Hall, E. R., McCully, V. \& Cottam, G. L. (1979) Arch. Biochem. Biophys. 195, 315-324

Hopkirk, T. J. \& Bloxham, D. P. (1979) Biochem.J. 182, 383-397

Ip, M. M., Ip, C., Tepperman, H. M. \& Tepperman, J. (1977) J. Nutr. 107, 746-757

Kohl, E. A. \& Cottam, G. L. (1976) Arch. Biochem. Biophys. 176, 671-682

Kohl, E. A. \& Cottam, G. L. (1977) Biochim. Biophys. Acta 484, 49-58

Krebs, H. A. \& Eggleston, L. V. (1965) Biochem. J. 94, $3 \mathrm{C}-4 \mathrm{C}$

Laube, H., Wojcikowski, C., Shatz, H. \& Pfeiffer, E. F. (1978) Horm. Metab. Res. 10, 192-195

Ljungstrom, O., Hjelmquist, G. \& Engstrom, L. (1974) Biochim. Biophys. Acta 358, 289-298

Lowry, O. H., Rosebrough, N. J.. Farr, A. L. \& Randall, R. J. (1951) J. Biol. Chem. 193, 265-275

Ochs, R. S. \& Harris, R. A. (1978) Arch. Biochem. Biophys. 190, 193-201

Parilla, R., Goodman, M. N. \& Toews, C. J. (1974) Diabetes 23, 725-731

Riou, J. P., Claus, T. H. \& Pikis, S. J. (1978) J. Biol. Chem. 253, 656-659 
Rozengurt, E., Jimenez de Asua, L. \& Carminatti, H. (1969) J. Biol. Chem. 244, 3142-3147

Scrutton, M. C. \& Utter, M. F. (1968) Annu. Rev. Biochem. 37, 249-302

Seubert, W. \& Schoner, W. (1971) Curr. Top. Cell. Regul. 3, 237-267

Seubert, W., Henning, H. V., Schoner, W. \& L'Age, M. (1968) Adv. Enzyme. Regul. 6, 153-187

Smith, S. \& Abraham, S. (1970) Arch. Biochem. Biophys. 138, 112-121

Sugawa-Katayama, Y. \& Morita, N. (1977) J. Nutr. 107, 534-538

Swick, R. W. \& Ip, M. M. (1974) J. Biol. Chem. 249, 6836-6841

Taunton, O. D., Stifel, F. B., Greene, H. L. \& Herman, R. H. (1974) J. Biol. Chem. 249, 7228-7239

Taylor, C. B. \& Bailey, E. (1967) Biochem. J. 102 , $32 \mathrm{C}-33 \mathrm{C}$
Taylor, C. B., Bailey, E. \& Bartley, W. (1967) Biochem. J. 105, 717-722

Unger, R. H. (1971) Diabetes 20, 834-838

Van Berkel, T. J. C., Kruijt, J. K., Koster, J. F. (1977) Eur. J. Biochem. 81, 423-433

Van Berkel, T. J. C., Kruijt, J. K., Van den Berg, G. B. \& Koster, J. F. (1978) Eur. J. Biochem. 92, 553-561

Vernon, R. G. \& Walker, D. G.(1968a) Biochem. J. 106, 321-329

Vernon, R. G. \& Walker, D. G. (1968b) Biochem. J. 106, 331-338

Weber, G., Singhal, R. L., Stamm, N. B., Lea, M. A. \& Fisher, E. A. (1965) Adv. Enzyme Regul. 4, 59-81

Weber, K. \& Osborn, M. (1969) J. Biol. Chem. 244, 4406-4412

Zalitis, J. G. \& Pitot, H. C. (1979) Arch. Biochem. Biophys. 194, 620-631 